\title{
Port of Bitung Development in North Sulawesi and Its Impacts on Loading and Unloading Commodities, 1954-2005
}

\author{
Hisna, Endang Susilowati, Agustinus Supriyono \\ Master Program of History, Faculty of Humanities, Diponegoro University, Indonesia
}

DOI: https://doi.org/10.14710/jmsni.v4i1.6152

\begin{abstract}
This article aims to analyze the development of the Port of Bitung in Received: North Sulawesi and its impacts on loading and unloading commodities in 1954-2005. In 1954, the port of Bitung was designated as an ocean port. Since then, activities at the port such as ship visits and loading and unloading commodities began to run well. The physical development of the Port of Bitung in the form of basic and supporting facilities functioned as supporting activities at the port. The main facilities of Bitung Port consisted of port area, port ponds, shipping lanes, docks, breakwater, and roads. Meanwhile, the supporting facilities consisted of warehouses, stacking fields, port

October 23, 2019

Revised:

June 13, 2020

Accepted:

June 15, 2020

*Corresponding Author: hisna1993@gmail.com administration offices, ship guides, parking lots, electricity or generator sets, loading and unloading equipment. The physical development of Bitung Port had an impact on increasing ship visits, loading and unloading commodities at the port. Loading and unloading commodities in Port of Bitung were in the form of plantation products and the daily needs of the people of Bitung and the surrounding area.
\end{abstract}

Keywords: Port of Bitung; Loading and Unloading; Commodities; North Sulawesi.

\section{Introduction}

Bitung is one of the regions in North Sulawesi Province, known as a city of trade, fisheries, industry, tourism, and ports. As a port city, Bitung is always crowded by large ships that are carrying out loading and unloading activities at the port (Zaenuddin 2014, 108). Before it was established as an ocean port in 1954, Bitung Harbor was only a place for fishing vessels from various regions in eastern Indonesia, such as North Maluku, Gorontalo, Sangir, and other areas around North Sulawesi. The arrival made Bitung coast became crowded. Over time, the coast turned into a fishing port (Sulistiyono et al 2003, 32).

In 1950 the vice president of the Republic of Indonesia Dr. Moh. Hatta alongside Minister of Public Works Ir. Laoh visited Bitung. Their arrival aimed to review Bitung fishing port which would be developed as a replacement for Manado Port. Manado Port was considered ineligible as an ocean port because it often experienced siltation. Therefore, the government sought a new port location and they chose Bitung as an ocean port perspective (Mustafa 1997, 16-17). One of the supporting factors to change Bitung to become an ocean port was its location in Lembeh Strait, so, the ships and boats that leaned on the port would be protected from wind and waves. By such conditions, Bitung was a gateway for commodities entry and exit from various regions in Indonesia such as North Maluku, Sorong, Central Sulawesi, Sangir, Gorontalo and other areas in North Sulawesi (Regional Planning Agency 1995, 3). The construction of Bitung Port began in 1950, it gradually started with swamps accumulation around the port. In 1953, a 90-meter long pier was built for the berths of ships and loading and unloading activities. Bitung Port construction was continued by improving port facilities such as docks, warehouses, port offices, stacking fields and so on (PT Pelindo IV 1996, 3). After the construction finished, in 1954 the First Lady, Fatmawati, inaugurated the Port as an ocean port (Purba 2015, 29). 
The development was supported by several hinterland regions such as Gorontalo, North Maluku, Tondano, Minahasa, Central Sulawesi, Bolaang Mongondow, Sangir and other areas among North Sulawesi. These areas were generally commodity producers of copra, cloves and (Mai 1984, 48-58). They bought daily necessities from Bitung such as sugar, rice, wheat flour, building equipment and other necessities for resale in their area (Beng 2016, 89). This trading activity created Bitung Port to become crowded with ships from various regions. Based on the description above, there are two issues we discuss in this article. First, Bitung Port's physical development from 19542005. Second, the effects of Bitung Port development on loading and unloading commodities in 1954-2005. It provides some explanations about pier development, warehousing, loading and unloading equipments, and other port facilities to answer the first problem on port physical development. Meanwhile, the number of ship arrivals are also analysed as well as the volume and type of commodities at Port of Bitung.

Studies on port had been conducted by Murphy et al. (1988). They discussed about contemporary perspectives on international ports based on the factual condition that international trade had been developed rapidly in the first quarter of the $20^{\text {th }}$ century. Based on research, they assumed that the port has a very important role in supporting international trade activities. Furthermore, they analyze several factors that influence the development and activities of a port so that it can support international trade. The operational effectiveness of a port is very influential on international trade activities which ultimately affect the national economy. However, their research is focused on several major international ports in the world, one of them is a port in the United States.

The other port studies are conducted by Sanchez et al. (2011). Their study discussed the main attributes of port that had been become an attraction based on the service provider's perspective. In line with the research of Murphy et al. (1984), Sanchez et al. (2011) explains that port activity has relevance to the economy, both at the local and national level. Port facilities are one factor that can support the economy at the local, national, regional and even international level. The availability of infrastructure can guarantee the implementation of international trade activities. The availability of trade commodities in the area around the port is also a determinant of the development of a port. As already stated, the development of activities at the Port of Bitung also received support from various regions in the vicinity.

Based on this background, both Murphy et al (1988) and Sanchez et al (2011), this study has relevance, especially to provide a context of ports from an international perspective. However, studies on ports are mostly studied from a macro perspective. In other words, small ports still receive less attention. In fact, even though it only accommodates trade commodities at the local level, small ports also have a role in supporting the national economy. Therefore, this article focuses on the development and loading and unloading commodities at the Port of Bitung which is one of the economic supports for local people in North Sulawesi and surrounding area.

\section{Method}

The method that has been used is a historical method by including four stages, heuristics, source criticism, interpretation, and historiography. Heuristics included primary and secondary sources. The primary sources in this research in the form of archival sources such as from archives from Bitung port office/PT Pelindo IV Bitung Branch, Bitung Port Administrator, Bitung Central Statistics Agency and North Sulawesi Province Central Statistics Agency, Bitung Development Planning Agency, North Sulawesi Trade Service, and National Archives of Indonesia (ANRI). While the secondary sources were dissertations, theses, articles, and books. After the sources were complete, the researcher conducted sources criticism, both external and internal criticism. External criticism aimed to determine sources authenticity, while the internal one aimed to obtain sources credibility. Then, the researcher interpreted historical facts to reconstruct past realities. Those historical facts were selected, analyzed and synthesized in chronological order. The last stage was historiography as an imaginative reconstruction of past events in the form of scientific writing. 


\section{Physical Development of Bitung Port}

Unlike other ports which were generally located at the river mouth, Bitung Port was located in the Lembeh Strait directly facing Lembeh Island, surrounded by hills, so, it could protect the port from wave disturbances. Therefore, throughout the year the Bitung Port was protected from the waves of Lautan Teduh Sea, that was Maluku Sea and Sulawesi Sea. Therefore, the ships could dock and safely do the loading and unloading. (Sarundajang 2011, 219). In 1954, the work area of Port of Bitung was determined, that was the surface area of water and land according to the Decree of Minister of Transportation No. 12/8, June 29, 1954. The working area was set at approximately 1307 ha, consisting of land/swamps of around 45 ha and sea surface area by 85.7 ha (Annual Report Port Administrator of Bitung 1984/1985, 18). Initially, it was inaugurated as an ocean port in 1954, then Bitung Port had a 90-meter long jetty and concrete floors. Beside a pier, the main facilities owned by the Port were A and B warehouses the port office, connecting road, security post and a 150 ton fresh water reservoir. In the same year, the construction of ocean pier was directed to westward, so, the whole pier length reached 207 meters, and the construction of a parking area was by 1,772 meters (Sulistiyono et al. 2003, 33). Port construction remained in progress in line with the construction of shipping traffic flow and the volume of loading and unloading of commodities (Padliansyah et al 2019). Among 1954-2005, the physical development of Bitung Port included basic facilities and supporting facilities. Basic facilities were in the form of needed facilities for the sake of shipping safety, berths, and loading and unloading commodities (Sasono 2012, 17).

The construction of basic facilities at Bitung Port in 1954-2005 included the port area, port ponds, shipping lanes, docks, break water, and connecting roads. The first basic facility was the port area. In 1954, the land area owned by the Port was 45 hectares. The land was used for the construction of warehouses, port offices, fresh water storage tanks, security posts, and roads (Kompas, February 10, 1995). Along with its development, until 2005 the port area increased to 388,050 hectares. Land addition was required to develop the port by adding area of parking, workshops, port offices, stacking fields, warehouses, roads, and coconut oil factories (Annual Report PT Pelabuhan Indonesia IV Bitung 2005, 27). Second basic facility was port pool. As an ocean port, Bitung Port had sufficient depth to qualify for the entry and exit of large-sized vessels at that time. Bitung Port's Pond had a depth of 15 meters and the wide of 4.33 hectares. Since the Port was protected by Lembeh Island, the sedimentation in the area was relatively small, so, the maintenance process on port pool depth was relatively small as well. Meanwhile, the beach condition around the port was steep and the seabed was full of sand. Tidal currents in the water around the port tended to east with a maximum height of 1.5 meters and a minimum of 0.90 meters and the current speeds reached three knots and the wind speeds reached six knots. Third basic facility was shipping lane. The shipping channel at the Port was nine miles-long and it was 800 meters wide. With such channel conditions, ships with a weight of 30,000 DWT could perform their activities safely and smoothly along the Bitung Port channel (Annual Report Port of Bitung Administrator 2004, 7). The fourth basic facility was a pier/mooring. During the period of 1954 to 2005, the total length of pier in the Port reached 1,706 meters. The entire pier could be used for all types of ships, from local ships to ocean ships. The names of piers in the Bitung Port could be seen in Table 1 .

Table 1. Pier/Mooring Facilities at Bitung Port among 1976-2005

\begin{tabular}{|c|c|c|c|c|}
\hline No Piers Name & $\begin{array}{l}\text { Length } \\
(\mathrm{m})\end{array}$ & $\begin{array}{c}\text { Wide } \\
(\mathrm{m})\end{array}$ & $\begin{array}{l}\text { Depth } \\
\text { (m) }\end{array}$ & Construction \\
\hline 1. Ocean Piers & 748 & 20 & 15 & Concrete, piling \\
\hline 2. Archipelago Piers & 602 & 10 & 6 & Concrete, piling \\
\hline $\begin{array}{l}\text { 3. Basic Chemical } \\
\text { Industry }\end{array}$ & 146 & 20 & 7 & Concrete, piling \\
\hline 4. Local Piers & 60 & 6 & 5 & Concrete, piling \\
\hline $\begin{array}{l}\text { 5. Bitung Container } \\
\text { Terminal }\end{array}$ & 150 & 20 & 15 & Concrete, piling \\
\hline
\end{tabular}

Source: Annual Report Port Administrator of Bitung 1976; PT (Persero) Indonesia Port Corporation IV Bitung 2005. 
The next basic facility was break water which was built in 1979. The break water construction was located at the Nusantara pier with a length of 100 meter. It protected the coast from waves. The last basic facility was the connecting road. The road network was one of the infrastructures that had an important role in supporting people and goods mobility to the port. Availability of adequate road facilities was encouraging port development, mainly among economic activity/loading and unloading of goods. The road construction within the Port was conducted in stages. In the early 1960 s the road in the Port area was only 300 meters-long (Annual Report Port Administrator of Bitung 1976, 12). The road was to support commodity goods transportation to the port. From 1962-2005 the length of the road at the Port has reached 6,040 meters. That length gave an impact on vehicles traffic that brought goods both in and out of the port, and being distributed around Bitung and inland areas (Annual Report PT Pelabuhan Indonesia IV Bitung 2005: 62-64).

Beside to daily necessities, Bitung Port was also supporting the necessities such as warehouses, stacking fields, port administration offices, scout ships, parking lots, electricity/generator sets, and loading and unloading equipment to assist loading and unloading activities at Bitung Port (Annual Report Port of Bitung 1997, 5). Warehouse facilities were one of the most important facilities in a port. Since 1954 the warehouse in the Port has been built with permanent construction and a roof with zinc, so, the goods stored in the warehouse were safe and protected from rain and sunlight. Warehouse existence was very important to protect goods from damage/possible loss if there was a ship delay. Ship delays were usually caused by certain unexpected problems, such as strong winds/storms. Goods commodity was not usually distributed to consumers, so, it was stored in a warehouse first (Annual Report Port Administrator of Bitung 1976, 36). Beside warehouse facilities, there was a stacking field served as a place to store heavy goods/containers. Other supporting facilities were 1,000-meter ${ }^{2}$ port administration office which was built in 1970 (Annual Report Port Administrator of Bitung 1976, 38). The port administration office served as a place for port management activities. All activities related to port management, supervision, community services and so on were conducted at the port administration office. Other important supporting facilities were parking. It was supported the port activity. In 1954 the parking lot at the Port reached an area of 1.772 meter $^{2}$. Over time, in 1988 the parking lot was expanded by piling up swamps around Bitung Port. Until 2005, the parking area at the Port was 2.394 meter $^{2}$. Besides parking, electricity networks and generators were also very important in supporting activities at the port. In 2005, there was an additional 555 Kilovolt Ampere (KVA) electricity grid, while there was an additional of 500 KVA for generator sets. This electricity and generator set facilities were mainly used for lighting facilities and office activities in the Port (Annual Report PT Pelabuhan Indonesia IV Bitung 2005, 34-35).

The development of a port was also inseparable from the appropriate facilities to support all activities in the port, such as loading and unloading equipment. Loading and unloading equipment was used to facilitate the loading and unloading of goods from ships to land and vice versa (Purba, 1997: 358). The development of loading and unloading equipment at the Port of Bitung was very diverse, for example in 1954-1990 the use of cranes and forklifts was not so dominant. Because there were still many human resources used to carry out loading and unloading activities at that time. Along with the rapid development of the Port of Bitung, the use of loading and unloading equipment was also increasingly diverse in order to support the loading and unloading of goods to be more effective and efficient. The development of loading and unloading equipment at the Port of Bitung in 19952005 can be seen in Table 2 .

The next supporting facility was the pilot boats. Pilot Boat at Bitung Port was divided into two types, namely marine pilot and harbor pilot. Marine pilot was assigned to guide ships, both ships on international and national shipping while sailing on the port channel; while the harbor pilot was responsible for guiding the ship to move in the harbor, both ships that would move from one place to another in the port pool and ships that want to move from the anchor to the dock to moor to unload and unload goods. Pilot boat personnel at the Port of Bitung were always standby to ensure the safety of ships that would enter/exit the Port of Bitung (Annual Report Port of Bitung 2005, 102). 
Table 2. Loading and Unloading Equipments at the Port of Bitung, 1995-2005.

\begin{tabular}{llrrrrr}
\hline \multirow{2}{*}{ No } & Types of Equipment & $\mathbf{1 9 9 5}$ & $\mathbf{1 9 9 7}$ & $\mathbf{1 9 9 9}$ & $\mathbf{2 0 0 2}$ & $\mathbf{2 0 0 5}$ \\
\hline 1. & Forklifts & 11 & 14 & 16 & 18 & 23 \\
2. & Cranes & 6 & 9 & 9 & 10 & 13 \\
3. & Container Handler & 3 & 5 & 7 & 7 & 9 \\
4. & Head Truck & - & 1 & 1 & 1 & 3 \\
5. & Tronton Truck & 1 & 1 & 2 & 2 & 3 \\
6. & Chassis & - & 1 & 2 & 2 & 3 \\
7. & Reach Stacker & - & - & 1 & 2 & 4 \\
8. & Top Loader & - & - & 1 & 1 & 4 \\
9. & Trailer & - & - & - & 1 & 3 \\
10. & Container Crane & - & - & - & - & 3 \\
\hline
\end{tabular}

Source: Regional Planning and Development Bitung 1995, See also

PT. (Persero) Indonesia Port Corporation IV Bitung, 2005.

\section{Effects of Bitung Port Development on Goods Loading and Unloading Activities}

\section{Ship Visits at the Port of Bitung}

Sea transportation is one of the most important means of transportation in Indonesia as an archipelago. Adequate sea transportation can facilitate the mobility of people and goods, therefore, goods needed in each region in Indonesia can be distributed throughout the country (Zuhdi 2014: 71). The Port of Bitung is one of the ten most important ports in Indonesia, after the ports of Belawan, Tanjung Priok, Surabaya, Semarang, Makassar, Palembang, Banjarmasin, Cirebon, and Padang. These ten ports are the main ports in Indonesia, both in serving inter-island shipping and ocean shipping. All of these ports are located in the Western of Indonesia, except Bitung and Makassar which are located in the Eastern of Indonesia. Of the ten ports, eight ports are located in the Java Sea region, namely Belawan, Tanjung Priok, Surabaya, Semarang, Palembang, Banjarmasin, Padang, and Cirebon. While the two ports are located in the sea of Sulawesi region, Makassar, and Bitung (Susilowati 2004, 221).

Table 3. Number of Cargo Arrivals at the Port of Bitung during 1969-2005 (in unit)

\begin{tabular}{llc}
\hline Year & Ocean Sailing & Inter-island Sailing \\
\hline 1969 & 506 & 1,798 \\
1972 & 532 & 1,820 \\
1975 & 498 & 1,997 \\
1978 & 637 & 2,472 \\
1981 & 793 & 2,653 \\
1984 & 486 & 1,941 \\
1987 & 730 & 2,749 \\
1990 & 697 & 2,156 \\
1996 & 825 & 2,758 \\
1997 & 943 & 2,597 \\
1999 & 1,629 & 4,641 \\
2002 & 1,238 & 3,399 \\
2005 & 1,647 & 3,570 \\
\hline
\end{tabular}

Source: Bitung Port Administrator 1973; Annual Report Port Administrator of Bitung 1984/1985. Annual Report of PT Pelabuhan Indonesia IV Bitung 1999-2005.

Bitung Port as the main port in North Sulawesi is a large and most important port. Since 1954, this port has become the economic chain in the region of North Sulawesi. In addition to being a place for goods loading and unloading activities, Bitung port is also a meeting point between sea and land transportation modes, such as ships and trucks (PT. Pelabuhan Indonesia Persero Iv 1966). The linkages between sea and land transportation networks of Bitung Port and others are very important. 
This is because the smooth transportation will also have an impact on economic growth and improvement in the region concerned, especially in the fields of trade, industry and economy. Cargo visits carrying merchandise such as copra and other plantation products at the Port of Bitung from year to year have increased. Cargo arrivals at the Port of Bitung in 1969-2005 can be seen in Table 3.

From the data in Table 3, it can be seen that after the Port of Bitung was developed into an ocean port in 1954, the number of ship arrivals, both ships on ocean and inter-island sailing had increased. Ships from abroad could directly enter and lean at the Port of Bitung to pick up merchandise, especially copra. It was because copra at that time was the main commodity exported from North Sulawesi (Mai 1984, 48-58). However, the number of ships on inter-island sailing was higher than the number of ships on ocean sailing. This was quite logical, because the ships used in ocean sailing were large ships weighing around 15,000 to 30,000 tons, so the numbers were certainly smaller as visits in sailing among smaller islands (Annual Report PT Pelabuhan Indonesia IV Bitung $2005,14)$. The relatively high increase was in the number of ship arrivals at the Port of Bitung, both in oceanic and inter-island sailing in 1999 to 2005, even during this period the number of ship visits experienced a great increase. Although in 2005 inter-island sailing declined slightly, the reduced ship visit did not affect the amount of goods unloaded at Bitung Port. This was proven in that year, construction materials such as cement and asphalt which were unloaded at the Port of Bitung showed a significant increase.

\section{Loading and Unloading Commodities at the Port of Bitung}

Freight traffic in Bitung Port colors the economic activities of Bitung City as a port city. The strategic location of the Bitung Port makes it a gateway for sea transportation from regions in Indonesia as well as in the Asia Pacific. The intensity of sea transportation can be seen from the loading and unloading of goods at the port. Inter-regional trade in Indonesia is quite dominant in this port. It is because Bitung is a trading center and transit point for merchandise from areas around North Sulawesi, North Maluku, and Central Sulawesi (Regional Development and Planning Agency of Bitung, 1995: 2). Transportation of crops and agriculture from the hinterland to the port is performed by sea or land, likewise, the distribution of daily necessities to the hinterland areas. Products such as copra, cloves, coffee, and soybeans are the mainstay commodities in the Port of Bitung. Most of these commodity trading destinations are still domestic such as Jakarta, Surabaya, and Makassar. Data on plantation commodities transported through the Port of Bitung cannot be presented at all due to limited resources. Plantation commodities transported through the Port of Bitung in 1969-2005 can be seen in Table 4.

Table 4. The Volume of Plantation Products Transported via Port of Bitung 1969-2005 (in ton)

\begin{tabular}{ccccc}
\hline Year & Copra & Cloves & Coffee & Soybean \\
\hline 1969 & 25,728 & 8,091 & - & - \\
1974 & 37,463 & 5,516 & 680 & 1,349 \\
1975 & 35,522 & 1,604 & 291 & 1,150 \\
1980 & 23,495 & 7,340 & 664 & 8,850 \\
1981 & 25,638 & 8,296 & 115 & 8,508 \\
1984 & 11,139 & 8,052 & 239 & 7,845 \\
1986 & 46,864 & 6,050 & 1,379 & 5,256 \\
1987 & 43,464 & 16,890 & 705 & 5,532 \\
1988 & 23,733 & 13,665 & 254 & 2,195 \\
1990 & 53,540 & 5,501 & 104 & 2,200 \\
1993 & 25,253 & 9,142 & 370 & 6,114 \\
1996 & 24,978 & 9,160 & 190 & 6,363 \\
1999 & 36,430 & 27,324 & 1,526 & 10,305 \\
2002 & 14,767 & 12,364 & 863 & 3,834 \\
2005 & 23,848 & 19,296 & 1,578 & 11,411 \\
\hline
\end{tabular}

Source: Rudini, et al. 1992; Central Bureau of Statistics of North Sulawesi 1980; 1983; 1984. 
North Sulawesi and surroundings are the largest copra-producers in Indonesia. Besides being processed into coconut oil in several companies in Bitung, copra is also transported by ship to various regions in Indonesia such as Surabaya, Makassar, and Jakarta. During 1969-2005 copra commodities transported via Bitung Port showed a significant increase on average, although it had fluctuations at times, likewise clove commodities. Unlike coffee and soybeans, copra and cloves were the mainstay of export commodities at the port of Bitung. Because Bitung and surrounding communities preferred to develop coconut/copra and clove plants, since the price of copra and cloves was higher than coffee and soybeans (North Sulawesi in Figures, 2005: 230). The activity of transporting plantation commodities at the Port of Bitung was undoubtedly affected by annual crop yields. In this case, the high / low number of plantation products loaded at the Port of Bitung depended on the yields of Bitung and surrounding communities. In addition, the availability of more adequate port facilities and increasingly routine ship visits also affected trading activities at the port, especially the trading of copra, cloves, coffee, and soybeans. The Port of Bitung was also a gateway for daily necessities which were unloaded at this port. These items are in the form of basic needs and construction materials as shown in Table 5.

Table 5. The Volume of Commodities of Basic Needs and Construction Materials entering the Port of Bitung 1979-2005 (in tons).

\begin{tabular}{ccccccc}
\hline Year & Rice & Sugar & Wheat & $\begin{array}{c}\text { Mixed } \\
\text { Goods }\end{array}$ & Cement & Asphalt \\
\hline 1979 & 26,532 & 16,800 & 19,200 & 14,728 & 65,672 & 5,408 \\
1981 & 50,643 & 29,685 & 19,800 & 17,599 & 70,146 & 6,520 \\
1983 & 46,619 & 29,700 & 22,200 & 15,422 & 74,239 & - \\
1984 & - & 26,076 & 21,200 & - & 20,063 & 4,381 \\
1987 & 44,763 & 25,969 & 23,026 & 23,475 & 48,728 & 8,120 \\
1989 & 46,796 & 17,550 & 18,959 & 24,862 & 103,203 & 6,569 \\
1992 & 47,500 & 22,298 & 16,932 & 29,643 & 114,957 & 6,330 \\
1994 & 39,136 & 20,740 & 17,556 & 24,160 & 57,218 & 8,241 \\
1996 & 58,425 & - & 19,135 & 16,756 & 210,403 & 7,832 \\
1999 & 51,611 & 18,400 & 31,154 & 14,656 & 163,281 & 3,431 \\
2001 & 19,373 & 23,700 & 23,415 & 11,523 & 67,200 & - \\
2003 & 43,720 & 20,150 & 20,812 & 16,849 & - & 2,800 \\
2005 & 27,869 & 13,537 & 21,375 & 31,193 & 295,790 & 5,062 \\
\hline
\end{tabular}

Sources: Central Bureau of Statistics of North Sulawesi 1979; Statistics Bureau of Bitung 2002; $2003 ; 2006$.

The development of plantation sector in Bitung and surroundings has resulted in a more focused population on plantation crops. Only a few populations grow rice. Consequently, foodstuffs must be imported from outside Bitung. Rice and other foodstuffs as well as construction materials such as cement and asphalt are goods transported in large quantities through the Port of Bitung. These are imported from Surabaya, Makassar, and Jakarta. From the data presented in Table 6, we can see fluctuations in the need for food, mixed goods, and construction materials (cement and asphalt) entering the Port of Bitung. During 1979 to 1983, the number of daily needs, mixed goods, and construction materials (cement and asphalt) which were unloaded at the Port of Bitung tended to increase. This was caused by the high demand for goods needed by the Bitung people, therefore, the amount of food, mixed goods, and construction materials unloaded at the Port of Bitung also increased (Central Bureau of Statistics of North Sulawesi 1983, 52). In 1984, there were no imports of rice and mixed goods, even at this time the commodity of sugar, flour, cement, and asphalt also declined. It was very possible that it depended on the needs of goods needed by the local community. During that time period, the highest foodstuffs entering the Port of Bitung were rice and sugar, followed by wheat and mixed goods. Meanwhile, the highest construction material was cement, followed by asphalt. Construction materials such as asphalt served to support the construction of roads, while cement was used to construct buildings, houses, and other needs. In addition to meeting the needs of Bitung people, the goods were also to meet the needs of the hinterland communities. 
The distribution of food goods and construction materials to the hinterland was performed by sea and land routes by using freight trucks (Lomban et al. 2009, 27).

\section{Conclusion}

The Port of Bitung is one of the largest ports in North Sulawesi. Previously, this port was only used as a place to rely on fishing ships from around North Sulawesi, North Maluku, Central Sulawesi, and other regions in Indonesia. The physical development of the Port of Bitung from 1954 to 2005 was supported by several factors. First, geographical aspects. The Port of Bitung is located in the Northern of Sulawesi Island and is directly opposite to Lembeh Island which naturally protects the port from waves and wind. Second, from the physical development, the facilities and infrastructure at the Port of Bitung have improved by the years in the form of basic facilities and supporting facilities. The adequate facilities can support and facilitate activities at the port, both loading and unloading as well as other activities. Third, since the Port of Bitung was developed into an ocean port in 1954, ship visits began to run smoothly. During 1969 and 2005, ship visits at the Port of Bitung showed an increase by the years. This was in line with the development of goods loading and unloading activities at the Port of Bitung. Commodities transported from the Port of Bitung are dominated by plantation products such as copra, cloves, coffee and soybeans. Meanwhile, the commodities unloaded at the Port of Bitung are foodstuffs in the form of rice, sugar, wheat, other basic needs, and construction materials such as cement and asphalt. In addition to being consumed by the Bitung people, some of these commodities are also distributed to hinterlands such as North Maluku, Sangir, Minahasa, Central Sulawesi, Gorontalo, Talaud, and other areas in North Sulawesi.

\section{References}

“Annual Report Port Administrator of Bitung 1976.” Bitung: Direktorat Jenderal Perhubungan Laut.

“Annual Report Port Administrator of Bitung 1984/1985.” Bitung: Wilayah VII Direktorat Jenderal Perhubungan Laut.

“Annual Report PT Pelabuhan Indonesia IV Bitung 2005.” Bitung: Direktorat Jenderal Perhubungan Laut.

“Bitung Pelabuhan Kecil dengan Kemampuan Besar”, Kompas, 10 Februari 1995.

Beng, Isra. 2016. "Dari Dermaga Ke Pelabuhan: Perkembangan Pelabuhan Sofifi Tidore Kepulauan Tahun 1975-2010.” Master Thesis Diponegoro University.

Bitung Port Administrator. 1973. Penuntun Singkat Pelabuhan Bitung. Bitung: Badan Pengusahaan Pelabuhan Bitung.

Central Statistics Bureau of North Sulawesi. 1980. Sulawesi Utara dalam Angka 1979.

Central Statistics Bureau of North Sulawesi. 1983. Sulawesi Utara dalam Angka 1982.

Central Statistics Bureau of North Sulawesi. 1984. Sulawesi Utara dalam Angka 1982.

Laporan Tahunan PT. (Persero). 2014. Pelabuhan Indoesia IV Cabang Bitung. Bitung: 2014.

Lomban, Max J. 2009. Bitung: Melangkah Pasti. Bitung: Bappeda Kota Bitung Kerjasama Yayasan Serat Manado.

Mai, Ulrich. 1984. "Small-Town Markets and the Urban Economy in Kabupaten Minahasa." Indonesia 37: 48-58.

Murphy, Paul, Douglas Dalenberg, and James Daley. 1988. "A Contemporary Perspective of International Port Operations." Transportation Journal 28 (2): 23-32.

Mustafa, Ismail, 1997. Sejarah Pelabuhan Bitung dari Pelabuhan Nelayan Menjadi Pelabuhan Samudera Tahun 1930-1983 (Skripsi pada Program Studi Jurusan Sejarah Universitas Sam Ratulangi Manado, Manado: 1997).

Padliansyah, Sutejo Widodo, and Endang Susilowati. 2019. “Terminal Kalibaru sebagai Solusi Mengatasi Kemacetan Bongkar Muat Peti Kemas di Pelabuhan Tanjung Priok Jakarta, 20112016." Indonesian Historical Studies 3 (1): 74-85 https://doi.org/10.14710/ihis.v3i1.5094.

PT. (Persero) Pelabuhan Indonesia IV. 1966. Anlisis Dampak lingkungan Pelabuhan Bitung Sulawesi Utara. Ujung Pandang. 
Purba, Jhon Rivel. 2015. Pelabuhan dan Heterogenitas Masyarakat Bitung 1950-2007. Yogjakarta: Kepel Press.

Purba, Radiks. 1977. Angkutan Muatan Laut I. Jakarta: PT Rineka Cipta.

Regional Planning and Development Agency of BitungBadan Perencanaan Pembangunan Daerah (BAPEDA) Tingkat II Bitung Tahun 1995.

Rudini. 1992. Profil Provinsi Republik Indonesia Sulawesi Utara. Jakarta: Pemrakarsa.

Sanchez, Ricardo J., Adolf K. Y. Ng., and Lorena Gracia-Alonso. 2011. "Port Selection Factors and Attractiveness: The Service Provider's Perspective.” Transportation Journal 50 (2): 141-161.

Sarundajang. 2011. Geostrategi; Sulawesi Utara Menuju Pintu Gerbang Indonesia di Asia Pasifik. Jakarta: Kata Hasta Pustaka

Statistics Bureau of Bitung. 2002. Bitung dalam Angka Tahun 2001.

Statistics Bureau of Bitung. 2003. Bitung dalam Angka Tahun 2002.

Statistics Bureau of Bitung. 2006. Bitung dalam Angka Tahun 2005.

Sulistiyono, Singgih Tri, and Susanto Zuhdi. 2003. Simpul-Simpul Serajah Maritim dari Pelabuhan ke Pelabuhan Merajut Indonesia. Jakarta: Kementrian Kebudayaan dan Pariwisata.

Susilowati, Endang. 2004. Pasang Surut Pelayaran Perahu di Pelabuhan Banjarmasin, 1880-1990. PhD Dissertation Universitas Indonesia.

Zaenuddin, H. M. Asal Usul Kota-Kota di Indonesia Tempo Doeloe (Jakarta: PT Zaytuna Ufuk Abadi, 2014).

Zuhdi, Susanto. 2014. Nasionalisme, Laut, dan Sejarah. Depok: Komunitas Bambu. 